\title{
Social Entrepreneurship seen by Social Entrepreneurs and the General Public
}

\author{
Malika Kna' ${ }^{1}$ hadija Kababi ${ }^{1}$ and Souad Tayane ${ }^{2^{*}}$ \\ ${ }^{1}$ Regional Center of Education and Training Trades Casablanca-Settat CRMEF -Morocco; \\ kna_malika@yahoo.fr, elkababi@hotmail.fr \\ ${ }^{2}$ National School of Arts and Crafts of Casablanca, Hassan II University of Casablanca - \\ Morocco; souadtayane2013@gmail.com
}

\begin{abstract}
Background/Objectives: With the time of change, inequalities, climatic change and social exclusion, the challenges facing our societies are multiple, and social entrepreneurship continues to assert itself as a vector of solutions. This study is to develop a barometer of social entrepreneurship, to build confidence in social entrepreneurs as to their ability to solve major societal problems. Methods/Findings: In all sectors of activity, it gives meaning to the economy and reconciles economic profitability and societal performance. Initiatives in this direction are numerous and are already preparing a new model of a more sustainable society, more just, more humane. A survey was conducted on the perception of social entrepreneurship among social entrepreneurs and the general public in Morocco. It revealed limited knowledge of social entrepreneurship among the general public. Application/Improvements: This study revealed a confidence of social entrepreneurs in their ability to solve major societal problems. But if the recognition of their impact by the general public is more and more shared, so to make known the action of the social entrepreneurs remains an important challenge.
\end{abstract}

Keywords: General Public, Perception, Social Entrepreneurs, Social Entrepreneurship

\section{Introduction}

With the inequalities, climatic change and social exclusion, the challenges facing our societies are multiple, and social entrepreneurship continues to assert itself as a vector of solutions. In all sectors of activity, it gives meaning to the economy and reconciles economic profitability and societal performance. Whether to fight against unemployment, to reinforce the development of sustainable financing tools, social innovation continues to prove that there is another way of conceiving the economy of tomorrow ${ }^{1}$.

Widelyused bydifferentmedia, social entrepreneurship is a relatively new concept, appeared in the early nineties with initiatives appeared in North America but also in the European continent.
Thus, Harvard Business School launched "The Social Enterprise Initiative" in 1993 as well as in Europe and more specifically in Italy, the creation of social cooperatives to meet social needs not covered by the state $^{2-4}$. Social entrepreneurship is an emerging concept for which there is no exact and precise definition. Different meanings are associated with this concept, which is used differently by different actors. However, two schools can be distinguished, namely:

- The American school that emphasizes on the individual, the entrepreneur who embodies a certain number of characteristics (ambition, will, commitment, perseverance, charisma ...) and who testify to the commitment of the social cause by investing in new ideas for a new way of development through 
innovative projects to face social problems such as unemployment, exclusion, social precariousness ...

Thus the American conception of entrepreneurship social insists on the entrepreneur as pivot for change in order to provide solutions to societal and environmental problems ${ }^{5}$.

- The European and particularly French school emphasizes on the characteristics of social enterprise, ESP Perception especially the objective of rendering a service to the community in a voluntarist approach of sustainable development where the economic dimension is not an end in itself it rather a tool to serve the social purpose.

Thus social entrepreneurship aims to meet one or more social needs by transforming them into economic business without supplanting the social purpose. However, social entrepreneurship aims to address issues of social, economic, environmental, through the creation of social institutions generating surplus value.

Social entrepreneurship isthe work of motivated people able to alienate or associate economic profitability and social spin-offs with new and innovative projects in order to change the daily life of the population. It can take many forms ranging from the creation of companies, foundations, cooperatives, associations, whose activities are very varied covering all areas: education, health, transport, crafts, agriculture.

\section{The Context of the Study}

Beyond the benefits of the globalization that we live and which are numerous, in particular the growth of the international trade, the opening of the national economy on a global market with technological transfers towards the countries of the south, the development of the cultural exchanges, Engaging a process of interdependence of national economies, globalization has also created economic, environmental and social disadvantages with problems of unemployment, precariousness, poverty and exclusion.

In this global and national context, the social economy has the merit of presenting itself as a new way of doing the economy and undertaking while having a social purpose. It is a new mode of economic management working for economic profitability without omitting to assert the social objective. Thus social entrepreneurship appears as an alternative to the so-called traditional entrepreneurship mode by providing innovative solutions that meet the needs and ills of society.

Inspired by the various research works analyzing the framework of the social entrepreneurial and mediatized in this context, our study aims to answer the following question: "How do we perceive social entrepreneurship and what are the motivations of social entrepreneurs"? This is to develop a barometer of the annual social entrepreneurship at the level of Morocco. So our research issues at the level of this study will be as follows:

- at what level is social entrepreneurship known?

- at what level are social entrepreneurs supported?

This study was conducted on the Casablanca-Settat region, the largest and most important region of the Kingdom.

According to the general monograph of the Casablanca-Settat region presented by the Ministry of the Interior, General office of Local Government ${ }^{6}$, The region of Casablanca-Settats' extends over an area of $2.7 \%$ of the national territory with $6,862,000$ inhabitants with a density of 353 inhabitants per square kilometer and an Area of 19,448 square kilometers.

This region comprises two prefectures, namely Casablanca Prefecture and the Prefecture of Mohammedia in addition to Seven Provinces, namely Settat, El Jadida, Sidi Bennour, Ben Slimane, Berrechid, Mediouna and Nouacer ${ }^{7}, \stackrel{8}{ }$.

It represents $20.3 \%$ of the total population of Morocco it is the first region in volume of population because it is the most populated of Morocco. It is also the country's leading economic region with a $32 \%$ share of national GDP.

The urban population represents $73.61 \%$ against $26.39 \%$ rural. In addition, compared to the Moroccan urban population, the population of CasablancaSettat represents 25\%, with a dominance of the axis of Mohammedia and Casablanca which represents $73 \%$ of the regional urban population.

Moreover, this region is home to the highest poverty rate compared to the national average according to the poverty map drawn up in 2007. Indeed, in Casablanca Settat this rate is $9.9 \%$ whereas it is only $8.9 \%$ on a national level. However, the rural population is more affected by poverty than the urban population. 
Thus the poverty rate is in the range of $2.5 \%$ to $27 \%$ in the city, while it varies between $0.5 \%$ and $25.6 \%$ in the countryside.

Finally, the economic and social indicators of the Casablanca - Settat region show the need for a second economic path that takes into account in addition to the economic aspect of the development of this region, the social and environmental aspect and especially of social cohesion. Hence the importance of social entrepreneurship as one of the solutions to consider in dealing with these social problems ${ }^{9-11}$.

\section{Methodology}

The general objective of this study is to identify the perception of social entrepreneurship by social actors. The survey covered 100 social entrepreneurs organized in organizations operating in different fields of activity: health, education, fight against illiteracy, non-formal education, income-generating activities, service sectors, etc.

The approach is the direct interview with social entrepreneurs having a responsibility in the offices of associations or in cooperatives or other forms of organizations and targeting activities intended to be marketed on the market.

But also the presentation of a questionnaire with 14 questions with specific objectives.

Two categories of officials were targeted by the interviews.

Those who are very active within the organization objects of the sample and therefore the interview with responsibilities of president, treasurer.

And those who are mere members, less active and who operate in these organizations.

In addition, there are four specific objectives, namely:

- The definition that social entrepreneurs give to social entrepreneurship, its usefulness, but also its ability to face the economic, social and environmental problems of our society;

- See the motivations of social entrepreneurs and how they perceive their participation in social cohesion;

- Approach the fields of action of social entrepreneurs and the possibilities of evolution to identify the potential offered by this social entrepreneurship;
- To ensure the importance of the role that social entrepreneurs give to the investment of the state and local communities to promote social entrepreneurship.

\section{Analysis of the Results}

- The priority for Moroccans: fight against unemployment in the face of climate change as expected, the focus on tackling unemployment is at the top of the agenda. Indeed, $48 \%$ of social entrepreneurs and 58\% of the general public identify the fight against unemployment as a major challenge to be addressed first. On the other hand, two years after the COP 22, climate change comes in 2nd place for $29 \%$ of social entrepreneurs surveyed and in 3 rd place for $17 \%$ for the general public. These figures reflect a growing awareness of the urgency of climate issues. For the general public, however, the question of poverty occupies the second place for $22 \%$ of respondents. Finally, on the social entrepreneurs' side, it is the lack of social cohesion which, for $11 \%$ of respondents, is the third highest concern. The contribution of social entrepreneurs in solving the main problem of society Faced with these challenges, social entrepreneurs remain optimistic (67\%) as to their ability to respond to societal problems. More moderate, the general public estimates that $30.6 \%$ that social entrepreneurs are useful to meet the challenges of society and considers for the first time as the most innovative actors in providing solutions, ex- with the social authorities, and behind the civil society with $33.7 \%$. $81.1 \%$ of social entrepreneurs are confident about the prospects for the development of the sector in Morocco and 75\% think that social entrepreneurship has a promising future. $71.7 \%$ expect to recruit in the coming year, demonstrating the sector's ability to contribute to the country's economic dynamism in a period of employability crisis. In addition, three out of ten Moroccans consider that social entrepreneurs contribute to social cohesion, particularly by promoting employment, training and professional integration (for $28.3 \%$ of respondents).

- A sector in search of notoriety While $75.5 \%$ of the general public has already heard of social entrepreneurship, only $44.3 \%$ have defined social enterprise as a life improvement, or a change of country or company created by the company or a 
company working for the social or an organization created to solve social problems.

$72.8 \%$ of respondents who admit to knowing the meaning of social enterprise, confirm already consume a product or service from a company with a social purpose, which shows that the sector finds a positive feedback sign of success.

- Ecosystem and partnership

Faced with many complex challenges they face, social entrepreneurs are developing more and more business models based on partnerships. These constitute one of the levers for the development of the sector: $76 \%$ of social entrepreneurs collaborate with traditional companies and $86 \%$ consider this collaboration to be positive. However, relations with public institutions are less important $56 \%$.

Concerning the partnership expectations of social entrepreneurs, the trends revealed by the survey reveal a transition from a logic based on sponsorship to a logic based on collaboration. Social entrepreneurs now expect less from their partners than they subsidize or provide opportunities for their products, but instead create lasting synergies with them.

- The obstacles to the development of the company according to social entrepreneurs

However, these results should not hide the reality. Only $18 \%$ of social entrepreneurs say they derive more than $50 \%$ of their income from the revenues of their activity, a sign that the economic model of many structures still needs to be consolidated. Social entrepreneurs still identify the lack of financial means as the main obstacle to their development (51\%), followed by the lack of partnerships with businesses (31\%).

\section{Conclusion}

Through this study we have reached several conclusions:

- Employment is crucial of new social entrepreneurs working to develop the employability of people in difficult situations. Initiatives promote the work of persons with disabilities, an audience with an unemployment rate four times higher than the national average.

- The development of innovative social projects will necessarily involve the creation of collaborations between social entrepreneurs, public authorities, traditional businesses, and research actors. These partnerships enable social enterprises to access new markets, expand the reach of their services, and acculturate traditional sectors to more inclusive and sustainable practices. The creation of these partnerships still faces many obstacles that will have to be overcome by creating trust between the players and by developing spaces for dialogue, collaboration and experimentation.

- Social enterprises, civil society and public authorities are considered as three complementary pillars of innovation to solve social and environmental problems.

- The reputation of the sector will partly be due to better communication on its impact. By demonstrating that they create jobs and generate positive social and environmental externalities, social entrepreneurs can increase industry recognition among the general public. Such communication nevertheless requires that the impact of social enterprises be measured. The assessment of this impact is sometimes perceived as inaccessible, despite the still tentative efforts in this area. These non-exhaustive elements make it possible to envisage a change of scale for social entrepreneurship. This evolution is not only desirable, it is necessary. The social issues we face no longer allow us to consider a company other than responsible and committed to the 21 st century. Social entrepreneurship is not only the sum of the initiatives that constitute it, but a movement that redraws the contours of the economy of tomorrow. It's up to us to collectively give him the means of his ambitions.

\section{References}

1. Huybrechts B. Fair Trade Organizations and Social Enterprise. Social Innovation through Hybrid Organization Models. Routledge, New York; 2012. p. 240.

2. Nicholls A. The legitimacy of social entrepreneurship: Reflexive isomorphism in a pre-paradigmatic field, Entrepreneurship Theory and Practice. 2010; 34(4):611-33. https://doi.org/10.1111/j.1540-6520.2010.00397.x.

3. ShortJC, Moss TW, Lumpkin GT. Research in socialentrepreneurship: Past contributions and future opportunities, Strategic Entrepreneurship Journal. 2009; 3(2):161-94. https://doi.org/10.1002/sej.69.

4. Stryjan Y. The Practice of Social Entrepreneurship: Notes Towards a Resource Perspective. Edward Elgar, Cheltenham; 2006. p. 35-55. 
5. Asli A, El Idrissi Slitine A. Social entrepreneurship in Morocco, Perception and development paths, Moroccan Journal of Research in Management and Marketing. 2012.

6. Rhihil A, Tayane S, Gassemi1 K, Zahouil M. Perception of Social Entrepreneurship in Morocco: A Building Site that is just to be Constructed, International Journal of Engineering and Technology. 2019; 8(11):56-63,

7. Kerlin J. Social Enterprise in the United States and Europe: Understanding and Learning from the Differences. International Society for Third-Sector Research and the Johns Hopkins University; 2006. 17, p. 247-63. https://doi. org/10.1007/s11266-006-9016-2.

8. Defourny J, Nyssens M. Conceptions of social enterprise and social entrepreneurship in Europe and the United States: Convergences and divergences, Journal of
Social Entrepreneurship. 2010; 1(1):32-53. https://doi. org/10.1080/19420670903442053.

9. General office of Local Government. Date accessed: 18/06/2019. https://statutes.capitol.texas.gov/Docs/SDocs/ LOCALGOVERNMENTCODE.pdf.

10. Report on Advanced Regionalization: General conception. Advisory Committee on Regionalization. Date accessed; 30/04/2010. https://41g41s33vxdd2vc05w415s1e-wpengine. netdna-ssl.com/wp-content/uploads/2018/07/regionalization_advisory_commsn_rept_0.pdf.

11. General Census of Population and Housing (RGPH) in Morocco. High Commission for Planning (Morocco). Date accessed: 16/03/2015. https://www.moroccoworldnews. com/2015/03/154096/morocco-population-reached-338-million-september-2014-census/. 